\title{
African Leadership Wisdom and Experience: Lessons for Church Leaders in South Africa
}

\author{
Zandisile M Dweba \\ CEO and Lead Consultant \\ Spontaneous Management Consulting \\ P. O. Box 3026, Cambridge \\ Southernwood 5201 \\ East London, South Africa \\ zandidweba@telkomsa.net \\ Reuben Z. Rashe \\ Associate, Centre for Theology and Religion \\ University of Fort Hare, Alice \\ South Africa \\ doi: https://doi.org/10.46222/pharosjot.102.25
}

\begin{abstract}
Christian research projects in Africa have been marred by a notorious and almost deliberate intent of seeking to establish alternative protocols that posit nothing less than the introduction of new objects of knowledge and new theoretical models that seek to upset or at the very least undermine the prevailing paradigmatic indigenous norms. In this article, the authors seek to demystify the complexities of "indigeneity" and "autochthony", and shed some light on how they impact the preservation of indigenous knowledge, values and norms. The indispensable social values which are deeply rooted in the African tradition, ubuntu and oral tradition are explored to suggest lessons from which church leaders can draw. This, the authors realise through a carefully structured literature review of selected sources. Following the reviewed literature, the authors must align themselves with the sentiments that, if the church in Africa wishes to enjoy relevance and acceptance, it has to approach African problems from an African perspective, liberate itself from the western 'garbs' or 'robes', and cease viewing everything African as pagan and devilish. Christianity, the authors contend, has a lot to learn, by accessing indigenous knowledge resources from the African people's culture and oral tradition.
\end{abstract}

Keywords: Indigeneity, autochthony, leadership, wisdom, culture.

\section{Introduction}

What seems to bother many African leadership and philosophy scholars is the problem of African people subliminally accepting and adopting the Western worldview and perspective with all its trimmings. The failure of Africans to recognise the roots and subtleness of these alien values and cultural ethos has led them to unconsciously abandon theirs. This has led them to be spectators in a show that defines them by outsiders. They find themselves participating in debates about their identity and culture based on alien terms. This dislocation has made it increasingly difficult for them to see themselves positively and constructively.

Given the foregoing, the sources of African leadership wisdom, from which church leaders can draw, have either been lost or abandoned. This is, even though Africa continues to be burdened with incompetent and even malevolent leaders, kleptocrats, economic illiterates and arrogant autocrats. Many African leadership and philosophy scholars, such as Gathogo (2008) and Ekeke (2011) are critical of the fact that Africans are not jumping at the opportunity to harvest and use African knowledge which already exists, owning it, and finding ways to 
improve it. By so doing, they continue to play into the hands of the colonisers whose aim has always been to colonise their minds and consciousness whilst undermining their indigenousness and indoctrinating them with the coloniser's ways (Mazama, 2001). People development in the African context - a lifetime process, must be taken advantage of, where the child passes through development stages with tailor-made methods of education that characterise each age set. Each gender has a unique role to play, with mothers generally focusing on educating girls while fathers focus on boys. African education is generally age-set linked, to ensure that the imparted knowledge is linked to a child's development and mental maturity. That knowledge, values and wisdom are instilled in children through songs, stories, praise poems, proverbs and riddles, makes the development so much more interesting and appealing to the child's playful mind. Church leaders in Africa have an opportunity to harvest these life-long lessons found uniquely from African leadership wisdom and experience grooming young boys and girls from an early age through adulthood. Experience, ubuntu and oral tradition are the most cited as the sources from which church leaders can draw. These, the authors discuss to lay bear the advantages whose value continues to illude our church leaders.

\section{African Leadership Wisdom and Experience}

The complex concepts of 'indigeneity' and 'autochthony' must be understood before any attempt is made to discuss the African leadership experience as they provide the foundation for whose culture and tradition is considered the norm in any given African community. Whilst the concepts are interrelated, their distinctiveness must be unbundled to facilitate understanding. The debate about autochthony and indigeneity, Pelican (2009) argues, are not immune to politicisation, and are influenced by the local context. This produces ambivalence and at times paradoxical outcomes. According to Hodgson (2002), because of the contextual nature of indigeneity, what are 'indigenous peoples' in one setting may mean something different in another. Whilst in some contexts, being the 'first people' might be uncontested, in some, the same uncontested indigeneity might be complicated by the peoples' histories and migration patterns, integration and conquests.

Kopytoff (1987) asserts that Africans sometimes reproduce themselves at their internal frontiers, and thus continuously recreating differentiation between the original inhabitants and latecomers. The Ngoni people of Malawi, who originally migrated from the Mzimba District of KwaZulu-Natal in South Africa, found themselves having to give away their ways and adopt the Tumbuka ways and those of the peoples they found where they settled in Malawi. As they compromised their ways, Mtenje and Soko (1998) lament, their language, tradition and culture got eroded. This, they contend, led to a hybrid culture composed of old forms, they brought with them and elements of the Tumbuka culture which they had to embrace, had crept into and diluted the Ngoni culture. What has also contaminated the concept of autochthony, is the idea of priority in time, i.e. 'first coming'. This led to the contestation of who arrived first and who are considered latecomers. The English equivalents and simplistic narratives of native, son or daughter of the soil, coupled with the negative opposites of stranger and migrant do not help in clarifying the discourse (Geschiere \& Nyamnjoh, 2000).

Ansell-Pearson (1987:57) initiated a pertinent debate by asking a question if, " $\ldots$ it is the function of our own and every age to grasp the knowledge which is already existing, to make it our own, and in so doing to develop it still further and to raise it to a higher level". To respond to Ansell-Pearson's question, the authors must ponder the various conceptions of African philosophy and how these respond to the African quest for identity, self-determination and liberation. Notwithstanding this noble aspiration, it would be naïve not to acknowledge that the development and evolution of management and leadership theories and practices in Africa have been enormously stifled by colonialism. Without so much as a consultation of the African natives, the western colonialists imposed western leadership and management theories as the panacea of Africa's social, political and economic development. Colonialism which brought 
with it Western scholarship and literature denigrated, deprecated and replaced the autochthonous heritage and wisdom inherent in African civilisations (Ansell-Pearson, 1987).

The African social context within which Christianity is lived is a challenge that our church leaders must traverse using context-relevant competencies. Failure to acquire these competencies may render the leaders ineffective in leading African congregations. This also calls for theological scholars to clearly and critically reflect and engage in pastoral missional praxis that is underpinned by a deep and vibrant faith in Christ. Such a reflection has the potential to create new opportunities to renew Christianity taking into consideration the African trends and ways, culture and tradition. For these leaders to enjoy the full benefits of African leadership wisdom, they must critique the power-play between the social context and Christ's mission through engaging in deep social analysis (Ilo, 2014). African philosophy in which is embedded African wisdom is constituted of logically coordinated thought on how the universe is structured, nature, humanity with all those things that surround humanity. Gathogo (2008) argues that there is a distinctly African philosophy, which is expressed in the belief systems among the Africans from time immemorial. His assertion is supported and strengthened by Oduyoye (2001) she writes that hospitality is "inherent in being African, as well as in adhering to religion that derives from the Bible..." It is "given a religious meaning, and linked with the ancestors, Christ and God." Our church leaders must understand that the African concepts of hospitality and ubuntu like African religion are quite broad and permeate all the spheres of life.

\section{Ubuntu as an African source of Leadership Wisdom}

Among the many autochthonous African resources is ubuntu leadership and management philosophy, which emphasises humaneness, communalism and African patriotism, which was negated by alien western ways. This disrupted the African peoples' cultural beliefs, traditions and ways of doing things. The destabilising effect of the importation of these western leadership and management theories and practices resulted in a clash with African leadership thought and practices. Inyang (2008:125) (Inyang, 2008)articulates this aptly when he cites Nzelibe's (1986:153) contention that, "Development of the principles of management was marred, however, by contact with the western world, contact marked by decades of economic exploitation, social oppression and the importation of scientific management, all of which have left acute problems for management today". The blanket imposition of these western practices and their willy-nilly prescription as a panacea for all African problems did nothing to help the development of the indigenous leadership and management theories and practices. It, instead, eroded the African leadership and the management thought system, replacing it with colonial training and development that was meant to psychologically emasculate the Africans of self and national identity (Osuntokun, 2001; Gbadamosi, 2003; Fashoyin, 2005).

Ayegboyin and Ishola (2011), caution that it is the establishment and growth of the strand of Christian development, during the nineteenth century, that triggered the emergence of African Indigenous Churches. It is the West, Central and South of Africa that have mostly been proliferated by these church formation. In South Africa alone, they contend, there are as many as 5000, if not more, African Indigenous Churches. As was alluded to, earlier, it is the looseness with which the terminology has been used to describe religious movements in Africa, that poses a problem in the labelling and the development of stereotypes on indigenous churches. Kruss (1985), alludes to an unending debate on what definition the African Indigenous Churches could be given, that would fit the religious stereotypes of the time. Some of the terms used to define African Indigenous Churches were acceptable whilst others were considered to be distasteful to the leaders of the Indigenous Churches (Ayegboyin \& Ishola, 2011; Masondo, 2014).

Mosala (1985) cited in Masondo (2014), argues that African Indigenous Churches, especially in South Africa, offered an opportunity for Africans to define who they are through highlighting, what it is, that is good for and about them $m_{2}$ and inculcate pride in their identity. These, Kiernan 
(1990), Masondo (2005) and Bompani (2008; 2010), agree, should be regarded as both Christian and African, since they align with Christian principles, African Religion, African as well as Western cultures and traditions. Amongst African Indigenous Churches, congregants appreciate their African culture, religion and values (Idang, 2015). Through this approach, church leaders can appeal to the congregants in familiar ways - ways they can identify with. Leonard (1966:429) cited in Ekeke (2011), asserts that, to Africans, their religion "...is their existence and their existence is their religion...they cannot get away from it". This, by implication, suggests that religion and secularity are inextricably intertwined. This overlap has not only created untold problems for onlookers who expect a clear dichotomy between the two. The blurring of spheres has created a conceptual pandemonium for scholars and theorists, who thought they could come up with a philosophy that would fit the African context and be acceptable to Africans. Credit must go to such scholars as Asouzu, Mbiti, Omorogbe, Onyewuenyi and Wiredu, who did and continue to do their utmost, to demystify African Religion (Ekeke, 2011).

For Mosala's aspiration of Africans defining who they are to be realised, the African continent would need to be 'reborn'. The 'rebirth', in Mbeki's (1998:298) words, must rebel - an "open resistance to authority...", to mitigate unstable politics in Africa, and put an end to "the mixture of greed, dehumanising poverty, obscene wealth and endemic public and private corruption practice" that led to many coups d'etat, civil wars and political instability (Mbeki, 1998; Malala, 2000). The call for an "African Renaissance" has since been echoed with repetitive monotony, for some time in the recent years, where an appeal is made to Africans to do some introspection, mend their ways, liberate themselves from the bondage of colonialism and engage with true African values. Such calls by scholars as Mugambi, Mbiti and Kwame Nkrumah of Ghana was meant to inspire the African people to achieve cultural, scientific and economic development without having to rely on external tutelage as African Renaissance viewed African art, music, language, cultures and customs as necessary for achieving African renewal (Tarus \& Lowery, 2017).

This call which is equally applicable to church leadership, emphasises the importance of development and learning of indigenous knowledge, grounded in leadership that is distinctly African and suited to African conditions. African Renaissance, these scholars maintain, must subscribe to the principles of community and identity. Notwithstanding this ambition, they argue, African leadership is not without challenges. Such challenges include over-functioning leaders - leaders who try to do everything and decide everything, and in the process, stifle the church processes; non-functioning leaders - who do not lead, but watch as the church dies; under-trained leaders - with inadequate training, that renders them incapable of performing optimally; Inappropriately trained leaders - leaders who have generic training, and lack doctrine-specific training, for the church they serve; over-extended leaders - who monopolise all the pastoral and sacramental functions, seeking to uphold the artificially high western standards of ministry, whilst denying the priesthood of believers; and, Springboard leaders - who use the church leadership training programmes, as springboards to secure suitable positions elsewhere, in government or para-church agencies (Douglas, 2014).

From an ontological perspective, scholars argue that different schools of thought (the social constructionist, the modernist and the post-modernist), arrive at fundamentally different conclusions about African leadership. From an epistemological perspective, they cite the difficulty that characterises the process of gathering and presenting knowledge about African leadership. Finally, they submit that the incidents of successful application of the principles of African leadership in an organisational context are few and far between. Against this backdrop, helpful sources, they argue, are rather the listening to how people experience leadership, leadership development and what they believe should be done to reincarnate the African leadership character and values (Koka, 1997; Louw, 1998; Mbigi, 2000; Ntibagirirwa, 2003; Mbeki, 2005; Obiakor, 2005; Olojede, 2005; Kirk \& Bolden, 2006). 
Whilst African nations had been subjected to the cruellest type of oppression and victimisation by colonial exploitation, racism and apartheid, it is unfortunate that when the issue of economic development and leadership were to be addressed, African church leaders and theologians focused largely on formulating indigenous theology, ignoring the role which the church needed to play as a contribution to economic development and leadership in Africa. This narrow focus on the cultural-religious dimension of economic and leadership development, later named, "inculturation theology", only emphasised the adaptation of the gospel message to suit the African context, at the expense, at times, of developing a theological stance on politics, leadership and economic dimensions (Bujo, 1992; Kwame, 1994; Kwame, 1997). The gospelculture 'obsession', Mveng (1994) argued, fixated the churches' on the limited role of doing charity work for the needy. By focusing on charity, church leaders lost the opportunity to be empowered and gain the courage to fight the systems and make a meaningful contribution, politically, socially, economically, to mention but a few.

At the risk of being seen as watering down the work of many deserving African leadership scholars, it must be acknowledged that some scholars contend that, it is nearly impossible to suggest an all-encompassing model for African leadership. This, they assert, is given the vastness of the continent and the diversity of its cultures. Notwithstanding, Hale (2004), proposes a 'compromise' model, that persons from a non-African cultural perspective could use to interface appropriately with the 'African culture', to exert spiritual, cognitive and behavioural influence. Whether or not, one views these negative views of African leadership as being Afro-pessimistic, many African scholars agree that the deplorable state of SubSaharan African leadership is well-documented. Most of them attribute the dismal performance to the leaders, choosing to abandon traditional styles of leadership in favour of Western leadership paradigms (Skinner, 1998; Okumo, 2002; Kamara, 2003; Nyabadza, 2004 \& Sunwabe, 2004).

Bolden and Kirk (2005) postulate that, for leadership development to have the desired impact, leadership capabilities must be identified and initiatives explored which are rooted in the participants' understanding of leadership development and how such development is likely to benefit their environments. The voices that should speak to the leadership development, must be those that seek the transformation, rather than bringing in alien 'experts', whose knowledge about the African context may be limited if existent at all. The approach to the development, Bolden and Kirk (2005) assert, must embrace African wisdom. This, they argue can be realised through the acknowledgement of the contributions and strengths of those who participate, using an experiential and interactive approach, as opposed to a didactic approach that is based on teaching. In this way, the African ways of thinking will be heard through the voices of the Africans about African leadership, which explores ways, through leadership, that facilitate beneficial social change within societies. As captured through the concept of ubuntu, leadership development must be grounded on the African humanist philosophy of interconnection to be relevant. It must offer a buffer between individualism and community. This supposes that self only has meaning if seen and understood as integral to the community. This must be founded on the philosophy of coexistence (Louw, 1998; Van Der Colff, 2002).

Post-colonial Africa, Dolamo (2013: 1) argues, must “...recapture the values and principles enshrined in the philosophy of botho/ubuntu, if its people are to enjoy the dignity that they deserve". This is the golden link', which the Western missionaries missed. This, Sigqibo Dwane bemoaned, for the Western missionaries were supposed, as required in their Christian affiliation, to treat fellow congregants equally and with dignity and that, the agape love had to begin with the love for fellow human beings. This is the essence of ubuntu - the golden thread which runs through, beliefs, religions, cultures and sub-cultures, tribes and other divides. It is not surprising that the founders of the Ethiopian Episcopal Church in South Africa perceived what the mission-driven church was and what it was doing, as unethical and contradicted the nondualistic notion of ubuntu (Sokupapa, 2018). The behaviour of these missionaries, in reality, flew in the face of peaceful neighbourliness, reconciliation and forgiveness, which are 
the cornerstones of ubuntu and a critical consideration if the church was at all serious about filling the interracial and intercultural void.

In a study of the prevalence and demonstration of ubuntu, undertaken at the Anglican Diocese of Harare, the institution was found not to embrace ubuntu and servant leadership (Meylahn \& Musiyambiri, 2017), although, ubuntu and servant leadership were considered pivotal in offering leadership as a values base and that emphasised service and community. Meylahn and Musiyambiri's (2017) contention echoed Broodryk (2006), cited in Msila (2008) when he wrote that ubuntu embraces values of community, sharing, love, respect, empathy, compassion, humaneness, giving, caring, warmth, sharing and commitment. This is consistent with Mangaliso's (2001:24) definition of ubuntu, as, “...a pervasive spirit of caring and community, harmony and hospitality, respect, and responsiveness that individuals and groups display for one another". He argued that this is foundational, for the manner Africans connect, and behave towards fellow humans, whether or not they are known to them (Meylahn \& Musiyambiri, 2017).

Whilst the values enshrined in ubuntu are ideal and should be embraced by leadership in both churches and the community at large, Nthamburi (2003) in Mugambi and Nasimiyu-Wasike (2003), lament that ubuntu values have been compromised and that African leaders have long lost the ubuntu philosophy. This, Van Den Heuvel (2008) attributes to ultra material wealth which had caused societies to lose their spirituality and cultural identity. This, he argues, has unfortunately created a capitalist setting where a few elites prosper. The absence of these values, he argues, has resulted in lost checks and balances which Africans used as a standard for sanctioning and keeping wayward and anti-social leaders on the "straight and narrow". Whilst ubuntu philosophy is seen by scholars of the early twenty-first century as a symbol of respect, caring, sharing, warmth, giving, love, compassion, humaneness, empathy and commitment, the recent student-led fallist discourse (Fikeni, 2019), has mounted a vicious attack and even outright rejection of ubuntu philosophy, reconciliation and forgiveness, on which South Africa's democracy is founded, arguing, in the words of a student activist, Simamkele Dlakavu (Mail \& Guardian, 2016), that:

\begin{abstract}
Experiencing black life every day must piss you off. I can't smile through black pain. For me rage and anger are powerful tools. We're not going to get our land back or free education by playing nice. We need to be enraged. The unapologetic black rage I see from young people is beautiful and I think that's what we need.
\end{abstract}

Whether or not, the intended purpose of the foregoing statement was to inculcate a new culture that negates ubuntu, is a matter that poses a challenge and even a hurdle for those who still 'preach' ubuntu as a fundamental value on which leadership should be firmly rooted. Notwithstanding, the ageless assertion of Samkange (1980), was reiterated (Tutu \& Allen, 2011), that, ubuntu is an Afrocentric viewpoint that offers a moral barometer for leaders. It is characterised by patience, responsibility and accountability. Their assertion is supported by numerous other scholars that, in the post-apartheid South Africa and postcolonial Africa, the notion of ubuntu offers possibilities for nation-building, social cohesion, synonymous with care ethics and predicate most African principles, social thinking and values (Eliastam, 2015; Chisale, 2018; Mashau, 2019). Mashau goes further to suggest ubuntu as a remedy to the unbridled gluttony in the prosperity Gospel as ubuntu shall, he asserts, represent a theology of solidarity, hope, care, life, accompaniment and economic justice.

Breed and Semenya (2015) raise and attempt to answer several questions about ubuntu. Among these, is whether or not ubuntu is a culture or religion and what role it can play in reconciling South Africans. It is not surprising that even for an icon like the first democratic President of South African - Nelson Mandela, having suffered at the hands of the apartheid 
government, it was through the expression of ubuntu that he was able to find it in his heart to give his oppressors a 'second chance' by forgiving them.

A comparison of ubuntu with the biblical concepts of Koinonia and Diakonia brings about important learning and must be unpacked. Nicolaides (2010) from an Orthodox perspective views the entire communion (or fellowship [Koinonia]) as all followers of Jesus who are created in His Imago Dei and are called to serve others in a spirit of servant leadership and agape love. It is the sharing, partnership, fellowship, communion and participation that characterises Koinonia that narrows the gap between the two concepts. The nature of Koinonia calls for Christians to, in the process of cherishing the biblical Koinonia, also strive to live peacefully with fellow men (Rom 12:18). This is in agreement with the concept of ubuntu, which Tutu (1997:78) argues, elucidates that, "one's humanity is caught up and inextricably bound up in others" - one is human because others are. Healthy ubuntu, Smith, Deacon and Schutte (1999) suggest, unites people regardless of their race or gender. What is likely to give ubuntu the power to transcend race, gender and colour boundaries, Mdluli (1987), Mbigi and Maree (1995), Kamwangamalu (1999) and Poovan, du Toit and Engelbrecht (2006) attest, could be the many social values which are shared by members of other social groups. Ubuntu emphasises interconnectedness, trust, compassion, solidarity and sameness.

Similarly, the image of a servant leader conjures agreements and disagreements in how Christian church leaders operate. The argument is about where one draws a line between authority and authoritarianism or service and servility. Whilst the Christian church requires men and women with the talent to realise its mission in the world, this should not lead Christians to claim privileged positions. This becomes abundantly clear when Jesus cautions John and James when they claimed a privileged position, that they did not know what they wanted, as not "... even the Son of Man did not come to be served, but to serve, and to give His life a ransom for many" (Mark 10:45).

For Jesus, Diakonia is associated with the breaking of the bread, serving at the tables, caring for the poor, preaching, shepherding and guiding. Diakonia is about leaders serving rather than being served - being the Diakono of the community, so to say (Velázquez, 2014). Whether there is sufficient substantiation or justification in Ludeke's (2001) criticism that, whilst the Independent Churches of South Africa have encultured koinonia and Christianised ubuntu, they do this without a clear understanding of and insight into the real koinonia in Christ. Notwithstanding, Breed and Semenya (2015), concede that there is a commonality between ubuntu, Diakonia and koinonia, that one cannot selfishly regard himself or herself as independent from their community. This is similar to Battle (2000) as cited by Hailey (2008:4), that, "Ubuntu rests on the knowledge that human existence is inextricably bound to God's creation and that a solitary human being is a contradiction in terms". This is even truer to the concept of the Imago Dei, that all humans are created in God's image (Dwane, 1987; Goffman, 1990; Kessler, 2010).

Because of the neglect of the African leadership heritage and wisdom, the social mission of Christianity is facing a great challenge, due to there being not enough effort given to analysing the social context. This, Ilo (2014) argues, leads to theological analysis and submissions that are irrelevant, abstract and universalising, as opposed to pragmatic, concrete and realisable solutions. These realisable solutions, however, call for serious engagement in, and a clear understanding of the prevalent conditions within the society, praxis of accompaniment and social transformation. The questions that the solutions must respond to, inter alia, are, "...how can the church in Africa concretely engage the historical challenges of the moment, and cease the great harvest of faith in Africa to bring about the kingdom of God for Africa? What transformative theology can be proposed for realising the promises of God's kingdom in Africa through African Christianity?" (Ilo, 2014:117). 


\section{Oral tradition as a source of Leadership Wisdom in African societies}

The African knowledge systems and ways of thinking that make up the body of local wisdom informs and guides African societies. Books, Cooper (1983) argues, were not the basis of traditional African life. In the indigenous African societies, all communication, including education was done orally. Through the oral tradition, the African learned about their history, their role in society, their crafts and duties, communication skills and traditional myths and legends. Learning in the African context is a lifetime process, marked by rites of passage where the African child passes through various stages of age groupings, characterised by a system of education for each age set. While it is the responsibility of the parent to educate the child, it is the responsibility of leadership in a church setting, to take over and continue with the education as part of the church's development programmes. Mothers generally educate girl children, whilst fathers the boys (Cooper, 1983).

There are similarities between the Gikuyu people of East Africa and the Xhosa people of the Eastern Cape province, who are the dominant group in the Ethiopian Episcopal Church in South Africa in that, their oral tradition includes rituals, folktales, proverbs, riddles, praise lyrics, metaphors, dances and legends. The wisdom can be traced several generations back and is passed from generation to generation through these oral narrations (Mtenje \& Soko, 1998). In the Xhosa knowledge resources, is, for instance, a riddle, that, Qashi-qashi: "Ndinabantu bam babini bafika ndingekafiki endaweni": (Riddle: I have my two people who always arrive before me). Solution: Ngamehlo (eyes). The eyes can see things before the physical body reaches the place (Simelane-Kalumba, 2014).

Whilst the authors focus on the Xhosa knowledge system, as they are the dominant peoples within the membership of the Ethiopian Episcopal Church in South Africa, other African groupings are not necessarily excluded, as from time to time, reference is made to their knowledge systems and are included in the body of local wisdom. Names in Africa, whilst part of the oral art, are not usually mentioned under the components of the oral forms and as such is not intensely debated in this article. Oral art, Magwaza (2004) asserts, provides linguistic tools that were used to instil and maintain cultural, moral and social values and formed the basis of a society's morals, ethos, culture, direction, perceptions, norms and values. The 'language' adopted by a society, encouraged, rebuked and warned people against certain tendencies and thus construct a people's identity and moral value system. How the various forms of oral art achieved these ideals, varied as is evident in the following examination (Ntshinga, 1995; Magwaza, 2004; Simelane-Kalumba, 2014).

Folklore is considered as a vehicle through which culture is orally transmitted and is rooted in oral literature. It is an art of self-discovery which shapes and help a person rationalise the natural laws that they find around them. Its defining feature, especially among amaXhosa, is that it is readily realisable through oral transmission. Mpola (2007) asserted that memories of significant events and traditional customs and values are handed down orally to succeeding generations when he wrote that:

Every nation or tribe has its folklore... its folktales which attempt to explain to
the people its past through its legends as well as its historical traditions.... It
has its heroes and renowned chiefs whose glory and worthy acts of valour
have been preserved in their eulogies or praises and blame poems, its war
songs and lullabies...and proverbial expressions (Mpola, 2007:81).

Among the components of folklore contained in oral literature, Ntshinga (1995), cites Xhosa folktale, riddles, songs, oral poetry, kinship group praises, proverbs and idioms, and proverbial names. In existence in Xhosa folktale are numerous genres, which are transmitted through both written and oral media. Each of the genres, Ntshinga (1995), argues, features its style and content. These include oral narratives (iintsomi), songs (iingoma), proverbs and idioms 
(izaci namaqhalo), riddles (amaqhina) and names (amagama). In these genres, which are delivered with dramatic performance, metaphoric language and body movement, people's feelings, hopes, fears, aspirations, perceptions and experiences are expressed. Xhosa stories, whether these are fictitious (iintsomi) or are historical happenings (iimbali), are laden with serious teachings and an implicit ideology of socialisation. Their strength and familiarity, Simelane-Kalumba (2014) contends, lie in the fact that though they are not facts, they draw on the values, customs and expectations that constitute the identity of the Xhosa people. They carry with them, the general themes of acceptable behaviour, knowledge, respect (intlonipho), imminent danger, the way of life (beliefs and customs), life skills and animal imagery to carry their valuable lessons. To grab the attention of the listeners, for instance, the expectation of the storyteller in iintsomi, is for the listener to intermittently say "Chosi", as an indication of their attentiveness. This is critical in any form of communication, be it at church or in the corporate setting. To safeguard against the use of work time for storytelling, iintsomi are only told after sunset. This was said to stop the horns from growing on their heads because it was believed that if iintsomi were told before sunset, the listeners would grow horns.

Riddles (amaqhina), are oral puzzles that have been passed down by word-of-mouth and whose solution is usually a familiar object or natural phenomenon. They form part of the Xhosa and other African oral traditions. They are usually used as curtain-raisers before the narration of folktales. All of this is part of traditional education and is used to train the youth to decipher coded language (Mtenje \& Soko, 1998). In the riddles, the initiates learn the language spoken by adults, in other words, a word may have two meanings, the surface meaning which is intended for children and the deeper one which is only understood by elders. Common riddles among the Xhosa people may be about human beings, animals, food, natural phenomena, etc. A few examples are cited below:

Riddle: 'I have twin sons standing on either side of the mountain-forest edge, supporting the forest in case it collapses.'

Solution: Human ears (twin sons), head (mountain), forest (hair).

Riddle: 'I have a woman who carries a bearded baby on her back.'

Solution: The maize stalk (woman), maize cob (baby) and the outer covering husks (beard).

Riddle: 'I have a woman. She has very many children and they are seen covering a great plain with the mother in the midst of them. But whenever her husband approaches, she and her children hideaway.'

Solution: The moon (the woman), the stars (many children) and the sun (the husband).

Notwithstanding this wealth of African leadership repositories, Africa continues to be a continent in transition. Obiakor (2004), laments that Africa's education, politics, and society, are not reflecting the $21^{\text {st }}$-century trends. As it appears, he contends, African leadership is still tied to European-centred frameworks that undermine the African people's wisdom and cultural heritage.

Proverbs are complementary to tales and require the person to whom they are expressed, to have undergone some initiation to understand their meaning. They are learned expressions of the wisdom and knowledge of elders. In Nigeria and other West African countries, for instance, proverbs are regarded as the 'condiment' which are used to add flavour to words. They spice the language. When a person adds proverbs in their speaking, by any African standard, such a person is considered to possess an exceptional command of the language. The skill is often demonstrated and witnessed during negotiations and mediation. During these instances, proverbs are seen as a sign of wisdom. Many themes are found in African proverbs, 
isiXhosa in particular, about animals, human beings, historical events or even seasons. 'Inyathi ibuzwa kwabaphambili', is a Xhosa proverb about animals, that is used to warn newcomers to take counsel from those before them before acting. The proverb originated from hunters, who would be tracking a buffalo they had wounded earlier. It was considered wise to ask those before you for what direction the buffalo could have taken (Mtenje \& Soko, 1998; Simelane-Kalumba, 2014).

'Inkonjane iliphangele ihlobo' is also a Xhosa proverb about swallows (birds). Swallows are migratory birds. They track and follow summer between the southern and northern hemispheres. As winter approaches the southern hemisphere, they migrate to the northern hemisphere. Their appearance in the southern African skies was therefore associated with approaching summer. The proverb 'Inkonjane iliphangele ihlobo' became, therefore, associated with the timing of things and events or for someone waiting their turn before they spoke. Should they, therefore, speak out of turn, the proverb was used to call the out-of-turn speaker to order - 'it is not summer yet, and we do not expect to see swallows' (Mtenje \& Soko, 1998; Simelane-Kalumba, 2014).

It must be acknowledged that, whilst it is not the intention of the authors to paint a rosy picture of all African families and societies, families, extended kin and societies, play a crucial role in developing future and successful leaders. That there may be dysfunctional families and societies should not be construed to suggest that these families and societies lack positive characteristics. The role of the church in normalising these situations, is of the essence, to nurture the young up-and-coming church leaders and set moral and ethical standards for their aspired leadership.

The community's expectation of the African leader was that he would be strong in dealing with lawbreakers and govern according to the customs of the society. They were expected to promote the common good and ensure justice, peace and tranquillity. Van Rensburg (2007:57) supports the notion of the family link of African traditional leadership when he writes that:

\begin{abstract}
Early African societies were participatory and democratic. Consistent with Africa's communalist values everyone was included in the decision-making process. The process entailed extensive debate as might be needed for complex matters. It ensured that minority positions were given full consideration. Leaders were chosen according to the rules of the extended families or lineages. Lineage provided the unity and stability from which kingdoms and empires developed. It created the view that even nations are nothing but one big brotherhood.
\end{abstract}

Pobee (1993:278) reinforces this assertion when he defends the African traditional leadership and chieftaincy as having immensely contributed to good leadership in Africa - disputing any supposition that the current undemocratic and corrupt systems as reminiscent of traditional chieftaincy when he wrote that:

Traditional African culture has another thing that is conducive to democracy: it has a community epistemology and ontology which may be summarized as cognatus sum, ergo sum, i.e., I am because I have blood relationship. Others have said $-\mathrm{I}$ am because we are. To be a person with dignity is to be located in a community and to have a sense of community, sharing among the community which consists of the living, the dead, and those-yet-to-be-born, a community in which everyone has the possibility to bring a contribution. Surely such epistemology and ontology can be harnessed in the promotion of democracy. The task is to search for the institutions and structures by which to foster and deepen the sense of community which is part of the African theory of being and existence and to develop the institutions by which we keep out or restrain elements that assail the sense of community to which tradition 
invites us. But the basis of the community should not be blood or kin; it should be our common humanity as creatures of the one God.

The foregoing assertion is supported by Mulemfo (2001) when he insists that, in traditional Africa, if the leader showed tendencies to exceed his authority, or prosper at the expense of his people, this was reason enough, to have him considered unfit to rule and dethroned. Former presidents Muammar Gaddafi of Libia, Robert Mugabe of Zimbabwe and Omar AlBashir of Sudan stand out as the glaring examples of leaders who were dethroned for being seen by the masses as prospering and enriching themselves at the expense of the people of their countries (Moghalu, 2017). The leaders' behaviour and sense of responsibility, Van Rensburg (2007) argues, was prompted by their spirituality and their religious role, which he contends, was more important than their political and economic roles. Traditional leaders were thus, he concludes, spiritually-minded. To separate these various roles of a traditional leader and African Indigenous Churches is extremely difficult, if not at all impossible. This is clear from Archbishop Ngada's response to this question when he stated that:

\begin{abstract}
It is still very difficult to cut the line between politics and religion, even today. I don't understand how people can separate politics from religion. Even the mere existence of the mainline churches was political. They had a political agenda from abroad. We fought against their agenda and their politics. Again, those people who said the African indigenous churches were apolitical, they were not undertaking a political analysis. Those people are real hypocrites because even before 1912, before the African National Congress was founded, was formulated, the African independent churches, people and leaders, were fighting against the oppressing role that was killing Africans. And later traditional leaders, kings, and chiefs fought side by side with the African National Congress (Bompani, 2008:668).
\end{abstract}

There is a need to acknowledge that indigenous culture and tradition expressed in African wisdom is an invaluable source of learning for African Christian leaders. When these critical identifying features of a people are excluded from the system of learning in a given society, it negatively impacts the self-confidence and self-esteem of the affected people. The exclusion of indigenous knowledge from leadership development and its replacement with alien western knowledge, the authors may conclude, has major implications for the distribution of power and the development of indigenous knowledge resources, resulting in the under-utilisation of the indigenous cultures and knowledge systems.

\title{
Conclusion
}

In this article, the authors started by painting the tragic picture of the Africans' abandonment of their traditional ways, however unconsciously, and replacing them with alien Western methods, especially when developing their leaders. The tragedy is superimposed on the church setting where church leaders seem to have equally adopted to preach the Word and do theology in ways that the African congregants struggle to fully comprehend. Afrocentrism while not comprehensively unbundled in this article, is central to the authors' arguments, that place African experience at the heart of African lives, learning, attitudes, predisposition and shared perceptions, that allow for people to organise experiences in particular ways. African leadership wisdom expressed in lived experience, ubuntu and oral tradition, remain key sources of leadership wisdom that church leaders can harvest. The authors must express their concern that with African culture and tradition rapidly relegated to the fringes among the younger generation, there is a need for intensified visibility and the exhibition of cultural phenomena as music, dance, poetry to mention but a few, to reignite the Afrocentric consciousness among the current generation; the initiation and strengthening the discourse on culture and tradition, with cultural luminaries and traditionalists taking the lead; and, the inclusion of an Afrocentric consciousness agenda in the curriculum of the institutions of higher learning. 


\section{References}

Ansell-Pearson, K. J. (1987). The Question of African Philosophy and Kwasi. Journal of Humanities, 1, 75-90.

Asante, M. (1991). The Afrocentric Idea in Education. Journal of Negro Education, 60, 170179.

Ayegboyin, D. \& Ishola, S. A. (2011). African Indigenous Churches. Ojo-Lagos: Lagos State University.

Ayegboyin, D. \& Ishola, S. A. (2011). African Indigenous Churches. Ojo-Lagos: Lagos State University.

Battle, M. (2000). A Theology of Community: The Ubuntu Theology of Desmond Tutu. Interpretation, 54(2), 178-182.

Bolden, R. \& Kirk, P. (2005). Leadership in Africa: Meanings, Impacts and Identities. Studying Leadership Conference (pp. 12-13). Lancaster, UK: Lancaster University.

Bompani, B. (2008). African Independent Churches in Post-Apartheid South Africa: New Political Interpretations. Journal of Southern African Studies, 34(3), 665-667.

Bompani, B. (2010). Religion and Development from Below: Independent Christianity in South Africa. Journal of Religion in Africa, 40(3), 307-330.

Breed, G. \& Semenya, K. (2015). Ubuntu. Koinonia, and Diakonia, a Way to Reconciliation in South Africa? HTS Teologiese Studies/Theological Studies, 71(2), Art. \#2979, 9 pages.http://dx.doi.org/10.4102/hts.v71i2.2979.

Broodryk, J. (2006). Ubuntu: Life Coping Skills from Africa. Randburg: Knowledge Publishing.

Bujo, B. (1992). African Theology in its Social Context. Maryknoll, NY.: Orbis Books.

Chisale, S. S. (2018). ubuntu as Care: Deconstructing the Gendered Ubuntu. Verbum et Ecclesia, 39(1), a1790.https://doi.org/10.4102/ve.v39i1.1790.

Cooper, G. C. (1983). Oral Tradition in African Societies. Negro History Bulletin, 46(4), 101103.

Dolamo, R. (2013). Botho/Ubuntu: The Heart of African Ethics. Scriptura, 112, 1-10.

Dwane, S. (1987). Gospel and Culture. Black Theology Project, 18-25.

Ekeke, E. C. (2011). African Traditional Religion: A Conceptual and Philosophical Analysis. Lumina, 22(2), 1-18.

Eliastam, J. L. (2015). Exploring ubuntu Discourse in South Africa: Loss, Liminality and Hope. Verbum et Ecclesia, 36 (2),. http://dx.doi.org/10.4102/ve.v36i2.1427.

Fashoyin, T. (2005). Management in Africa. Lagos Organization Review, Vol. 1 (1), 43-45.

Fikeni, L. (2019, May 18). Lwandile Fikeni's Ruth First Speech on Rage in the Rainbow Nation is Indispensable. Retrieved from Mail \& Guardian: http://mg.co.za/article/2016-08-18protest-art-and-the-aesthetic-of-rage-social-solidarity-and-a-post-rainbow-sa

Gathogo, J. (2008). African Philosophy as Expressed in the Concepts of Hospitality and Ubuntu. Journal of Theology for Southern Africa, 130, 39-53.

Gbadamosi, G. (2003). HRM and the Commitment Rhetoric: Challenges for Africa. Management Decision, 41(3), 274-280. 
Geschiere, P. \& Nyamnjoh, F. (2000). Capitalism and Autochthony: The Seesaw of Mobility and Belonging. Public Culture, 12(2), 324-452.

Goffman, E. (1990). The Presentation of Self in Everyday Life. London, UK: Penguin Books.

Hailey, J. (2008). Ubuntu: A Literature Review. London: General Tutu Foundation.

Hale, J. R. (2004). A Contextualized Model for Cross-cultural Leadership in West Africa.

Virginia Beach, VA.: Regent University.

Hodgson, D. (2002). Introduction: Comparative Perspectives on the Indigenous Rights Movement in Africa and the Americas. American Anthropologist, 104(4), 1037-1049.

Ilo, S. C. (2014). Africae Munus and the Challenges of a Transformative Missional Theological Praxis in Africa's Social Context. Transformation, 31(2), 116-131.

Inyang, B. J. (2008). The Challenges of Evolving and Developing Management Indigenous Theories and Practices in Africa. International Journal of Business and Management, 3 (12), 122-132.

Kamara, S. (2003, April 02). AllAfrica. Retrieved from Africa News Service:

https://www.allafrica.com/stories/200304020420.html

Kessler, V. (2010). Leadership and Power. Koers, 75(3), 527-550.

Kiernan, J. P. (1990). The Production and Management of Therapeutic Power in Zionist Churches within a Zulu City. Lewiston: The Edwin Mellen Press.

Kirk, P. \& Bolden, R. (2006). African Leadership: Insights, Meanings, and Connotations. Leadership and Management Studies in Sub-Saharan Africa Conference (pp. 1-20).

Zanzibar, Tanzania: University of the West of England, Bristol.

Koka, K. (1997). The Afrikan Renaissance. Midrand: The African Study Programme/Pretoria: Ubuntu School of Philosophy.

KopyToff, I. (1987). The internal African Frontier: The Making of African Political Culture. In The African Frontier: The Reproduction of Traditional African Societies. Bloomington: Indiana University Press.

Kruss, G. (1985). Religion, Class and Culture: Indigenous Churches in South Africa, with Special reference to Zionist-Apostolics (Unpublished Doctoral Thesis). Cape Town: University of Cape Town.

Kwame, B. (1994). Understanding African Theology in the 20th Century. Themelios, 20 (1), 14-20.

Kwame, B. (1997). African Theology, in The Modern Theologians: An Introduction to Christian Theology in Twentieth Century, ed. David E. Ford. London: Blackwell.

Leonard, A. C. (1966). The Lower Niger and its People. London: Frank Cass.

Louw, D. J. (1998). Ubuntu: An African Assessment of the Religious Other. 20th World Congress of Philosophy (pp. 10-15). Boston, Massachusetts: Online at www.phys.uu.nl/unitwin/ubuntu_page.html.

Magwaza, T. (2004). Conversations with Women of the Shembe Church: Self Perceptions and the Role of the Zulu Culture in Formulating their Status. Empowering Women for Gender Equity, 60, 136-145.

Malala, J. (2000, September 2000). Mbeki Vows to hold Summit to its Pledge. Sunday Times. 
Mangaliso, M. (2001). Building Competitive Advantage from ubuntu: Management Lessons from South Africa. Academy of Management Executive, 15(3), 23-33.

Mashau, T. D. (2019). Prosperity Gospel and the Culture of Greed in Post-colonial Africa: Constructing an Alternative African Christian Theology of Ubuntu. Verbum et Ecclesia, 40(1), a1901. https://doi.org/10.4102/ve.v40i1.1901.

Masondo, S. (2018). Ironies of Christian Presence in Southern Africa. Journal of the Study of Religion, 31(2), 209-231.

Masondo, S. T. (2014). African Indigenous Churches' Spiritual Resources for Democracy and Social Cohesion. Verbum et Ecclesia, 53 (3), Art.\#1341, 8 pages. http://dx.doi.org/10/4102/ve.v35i3.1341.

Mazama, A. (2001). The Afrocentric Paradigm: Contours and Definitions. Journal of Black Studies, 31(4), 387-405.

Mbeki, T. (1998). Africa - the Time has come. Cape Town: Tafelberg.

Mbeki, T. (2005). Goals of Higher Education in Africa. Texas: USA/Africa Dialogue, No. 588.

Mbigi, L. (2000). In Search of the African Business Renaissance. Randburg: Knowledge Resources.

Meylahn, J. \& Musiyambiri, J. (2017). Ubuntu Leadership in Conversation with Servant Leadership in the Anglican Church: A Case of Kunonga. HTS Teologie Studies, 73(2), a4509.https://doi.org/10.4102/hts.v73i2.4509.

Mosala, I. (1985). African Independent Churches: A Study of Socio-Theological Protest, in J. W. de Gruchy \& C. Villa-Vicencio (eds.), Resistance and Hope: South African Essays in Honour of Beyers Naude. Grand Rapids: Wm. Eerdmans.

Mpola, M. (2007). An Analysis of Oral Literary Music Texts in isisXhosa - Unpublished PhD Thesis. Grahamstown: Rhodes University.

Msila, V. (2008). Ubuntu and School Leadership. Journal of Education, 44, 67-84.

Mtenje, A. I., \& Soko, B. (1998). Oral Traditions among the Northern Malawi Ngoni. Journal of Humanities, 1-18.

Mugambi, J. N. \& Nasimiyu-Wasike, A. (2003). Democracy and Reconciliation: A Challenge for African Christianity. Nairobi: Acton.

Mulemfo, M. M. (2001). Thabo Mbeki and the African Renaissance. Cape Town: Goodwood.

Mveng, E. (1994). "Impoverishment and Liberation: A Theological Approach for Africa and the Third World" in Paths of African Theology, ed. Rosino Gibellini. London: CSM Press.

Nicolaides, A. (2010). 'The Laos tou Theou - an orthodox view of the "people of God"', HTS Teologiese Studies/Theological Studies, 66(1), Art. \#372, 5 pages. DOI:

10.4102/hts.v66i1.372

Nthamburi, Z. (2003). Theology and Politics in Africa. Nairobi: Acton.

Ntibagirirwa, S. (2003). A Wrong Way: From Being to Having in the African Value System. Cultural Heritage and Contemporary Change, Vol. 7, www.crvp.org/ook/Series02/II7/Chapter v.htm.

Ntshinga, T. N. (1995). Kwathi Ke Kaloku. Mabopane: L. Z. Sikwane Publishers.

Nyabadza, G. W. (2004, March 12). Africa News Service. Retrieved from Leadership at the peak - Africa needs dedicated leaders.: 
https://www.theindependent.co.zw/2004/03/12/leadership-at-the-peak-africa-needsdedicated-leaders/

Nzelibe, C. O. (1986). The Evolution of African Management Thought. International Studies of Management and Organization, 16(2), 6-16.

Obiakor, F. E. (2004). Patriotic African Leadership Through African-Centered Education. Journal of Black Studies, 34(3), 402-420.

Oduyoye, M. A. (2001). Introducing African Women's Theology. Sheffield: Sheffield Academic Press.

Okumo, W. (2002). Good African Leaders: Who are they and How do we get them? The Perspective, 1-6.

Olojede, D. (2005). Africa Insight. Dar es Salaam: Tanzania: Citizen.

Osuntokun, J. (2001). Some Thoughts on Traditional African Idea of Management. The Journal of Cultural Studies, 3(1), 99-107.

Pelican, M. (2009). Complexities of Indigeneity and Authochthony: An African Example. American Ethnologist, 36(1), 52-65.

Pobee, J. S. (1993). An African Christian in Search of Democracy, in Christianity and Democracy in Global Context, edited by J. Jr. Witte (pp. 268-386). Boulder: Westview Press.

Samkange, T. M. (1980). Hunhuism or ubuntuism: A Zimbabwe Indigenous Political Philosophy. Salisbury: Graham Publishing.

Simelane-Kalumba, P. I. (2014). The Use of Proverbial Names among the Xhosa Society: Socio-Cultural Approach (Unpublished Thesis). Cape Town: University of the Western Cape.

Skinner, E. P. (1998). African Political Cultures and the Problems of Government. African Studies Quarterly, 2(3), 17-25.

Sokupapa, T. C. (2018). Ecumenical Ecclesiology in the African Context: Towards a View of the Church as Ubuntu. Scriptura, 117, 1-15.

Sunwabe, C. K. (2004, March 24). The Perspective. Retrieved from Decrying the African predicament: http://www.theperspective.org/2004/mar/africanpredicament.html

Tutu, D. M. \& Allen, J. (2011). God is not a Christian: And Other Provocations. New York: Harper One.

Van Der Colff, L. (2002). Ubuntu, Isivivane and Uhluhlsa: The Meaning of Leadership and Management in South Africa. Workinfo.com Online, www.workinfo.com/free/Downloads/91.

Van Rensburg, G. (2007). The Leadership Challenge in Africa: A Framework for African Renaissance Leaders. Pretoria: Van Schaik Publishers.

Velázquez, E. (2014). Leadership, Authority and Power: in the Light of Biblical Ecclesiological Models. Didache: Faithful Teaching, 13 (2) Winter, 1-13.

Villa-Vicencio, C. (1988). Trapped in Apartheid: A Socio-theological History of the Englishspeaking Churches. Maryknoll: Orbis Books. 